\title{
Dependence on social network site: a multidimensional approach to benefits, trust, and use
}

\author{
Edgardo Bravo, Universidad del Pacífico,er.bravoo@up.edu.pe \\ Ana Gabriela Cuentas, Universidad del Pacifico,ag.cuentasr@up.edu.pe
}

\begin{abstract}
Facebook has emerged as the most popular social networking site (SNS). The literature has extensively studied factors that explain the continued use of Facebook. However, less attention has been paid to the dependence on SNS. Previous literature focuses on the study of dependence as an addiction. However, for most users, the social network does not become problematic but rather a feeling of the intense hook but not troublesome. Based on the smartphone literature, a model is proposed that explains dependence based on the benefits it provides, trust with the platform, and frequency of use. Data was collected from 240 users and analyzed using the partial least squares technique (PLS). The results empirically support the model. These findings allow us to become aware of the causes that can make users dependent, albeit not in a dysfunctional way.
\end{abstract}

Keywords: dependence, benefits, trust, use, SNS

\section{Introduction}

Facebook has emerged as the most popular social networking site (SNS) with over 2.6 billion users (Statista, 2019a). As of the third quarter of 2020, 73\% of Facebook users in the United States were reported to use this SNS daily (Statista, 2020). This SNS offers its users a unique value proposition through benefits, which become a crucial concept in competitive strategy (Hu et al., 2015). However, nine percent of U.S. Internet users considered themselves addicted to social networks, while $30 \%$ said they were somewhat dependent on this SNS (Statista, 2019b). These facts show us the relevance to study and understand why people depend on an SNS.

The literature on social network dependence has focused on two strands. Media Dependency Theory (MDT) conceive dependence as a relationship where the user relies on an SNS to accomplish goals or obtain benefits (Jung et al., 2012). This research considers mainly dependence as an independent variable to explain phenomena such as continuance intention (Chiu \& Huang, 2015) or online shopping (Bianchi et al., 2017). The second strand conceives dependence as addiction or problematic use. This research highlights the negative effect of dependence on people's lives (i.e. Burnell \& Kuther, 2016; Gerhart, 2017; Lin et al., 2019).

However, social network dependence cannot be, for the bulk of the population, problematic or addictive (Lin et al., 2019). A similar conception exists in the cell phone use arena, where dependence is a hooked feeling on SNSs (Hooi Ting et al., 2011; Suki, 2013). This gap offers an opportunity to investigate the dependence under the latter yet unexplored stream. Based on models of smartphone dependence (Aslam et al., 2018; Fan et al., 2017; Rosaline \& Johnson, 2020), this study proposes and empirically evaluates a 
model where expected benefits, trust, and frequency of use contribute to form an individual's dependence. The theoretical contribution of the study focuses on introducing a model that explains dependence understood as a sense of high engagement. In practice, the model can be used to design strategies that encourage engagement with the social network and discourage its abandonment.

\section{Literature Review}

Table 1 summarizes representative articles that explain dependence (under different conceptualizations) in the SNS context. The last column synthesizes the factors that trigger direct or indirectly this variable.

Table 1. Empirical studies explaining dependence on SNS

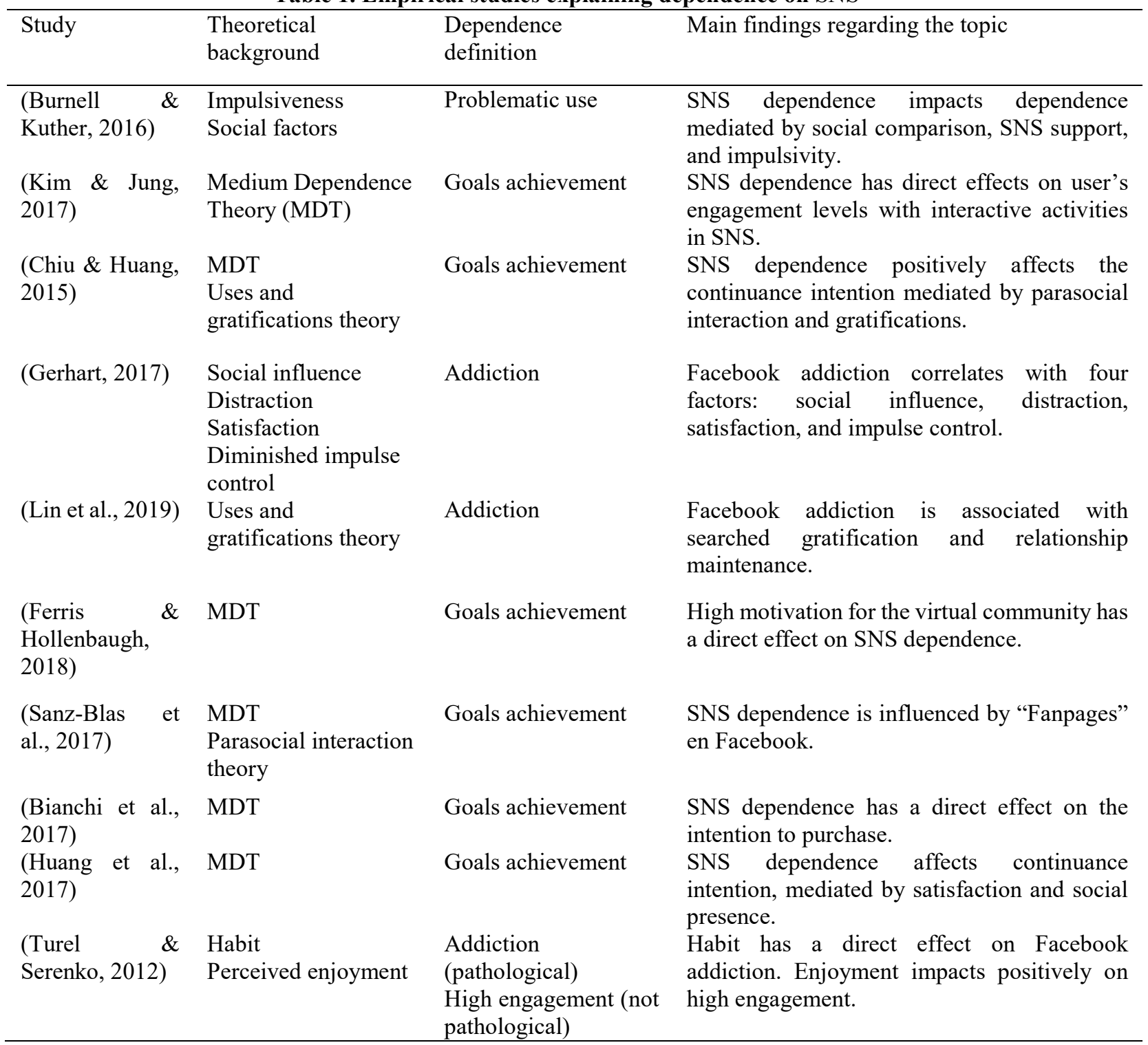

The review identifies two principal paths. While MDT studies dependence as a constant seeking to achieve goals, the studies centered on addiction aim to understand the dysfunctional factors that provoke this problematic behavior. 


\section{Theoretical development}

\section{Dependence}

Dependence in the field of technology and especially SNS is defined in different ways. MDT explains dependence as that relationship where the individual relies on the SNS to reach their goals (Jung et al., 2012). Therefore, it is the perceived usefulness of a means and its resources to achieve those goals (Jung, 2017). By contrast, some authors define dependence as an equivalent to addiction or problematic use, where dependence is an impediment to develop daily activities and external help is needed for its control (Burnell \& Kuther, 2016; Turel \& Serenko, 2012).

Authors studying intelligent phones understand dependence as the need for cell phone use and a strong propensity for continuous usage ( $\mathrm{Li} \& \mathrm{Lin}, 2016$; Suki, 2013). However, this dependence is distinct from problematic use or addiction because it does not involve dysfunctional use of the technology. Dysfunctional use reflects uncontrolled behavior that involves consequences in daily user life (Billieux et al., 2015). These effects could be overuse, financial problems, sleep disturbances, dangerous use, or prohibited use (Billieux et al., 2015; Middleton \& Cukier, 2006). Dependence as a not dysfunctional issue is conceived as feeling engaged and presenting resistance to detachment from the technology, in which the individual can function without external help (Hooi Ting et al., 2011; Tian et al., 2009).

For the present research, the focus will be on studying dependence as defined by the latter authors.

The studies mentioned in the literature review do not explain dependence as an engagement, so exploring new theoretical bases to understand this phenomenon is necessary. The smartphone literature suggests that expected benefits (Hooi Ting et al., 2011; Suki, 2013) would play a relevant role. Likewise, other fields indicate that trust and frequency of use could influence dependence. Figure 1 summarizes the research model, which is developed in the following paragraphs.

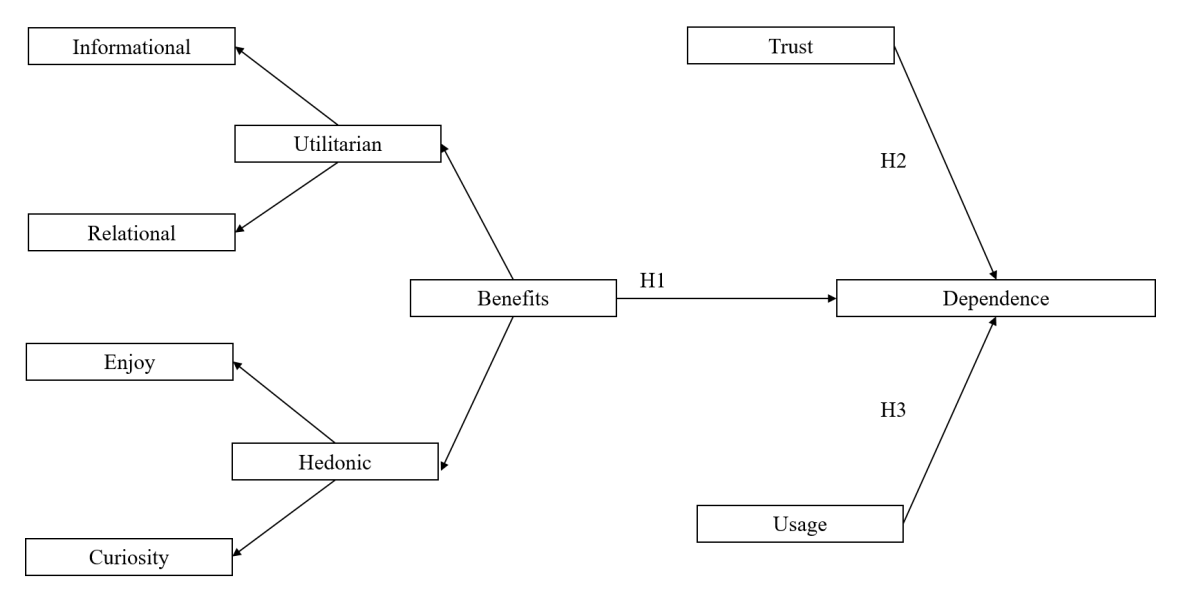

Figure 1: Research Mode

\section{Benefits}

SNSs -like Facebook- provide different types of benefits to their users. On the one hand, utilitarian benefits are those instrumental gains that the individual deliberately seeks when using the social network (Gan \& Wang, 2017). These types of benefits are relational and informational (Hu et al., 2015). Relational refers to 


\section{Issues in Information Systems}

Volume 22, Issue 2, pp. 157-167, 2021

when individuals create and maintain their social capital (Ellemers et al., 1999; Hu et al., 2015). Informational refers to when users exchange and share personal and general information (Hu et al., 2015).

On the other hand, hedonic benefits are oriented towards obtaining enjoyment and fun (Gan \& Wang, 2017). When the individual is immersed in an environment of pleasant experiences, he or she obtains two types of benefits: enjoyment and curiosity (Hu et al., 2015). Enjoyment comprises pleasurable experiences just for the sake of using the platform, while curiosity reflects individuals' cognitive exploration in the search for new experiences (Agarwal \& Karahanna, 2000; Hu et al., 2015).

Higher dependence implies that the individual has experiences how the SNS meets their needs (Keaveney \& Parthasarathy, 2001). To the extent that individuals perceive that the social network enables them to obtain benefits (fulfillment of needs and goals), users will reinforce their dependence on the platform (Chan et al., 2016).

Studies on smartphones (Park et al., 2013; Rosaline \& Johnson, 2020; Suki, 2013) showed that different benefits-social needs, access convenience, performance expectancy, perceived enjoyment - were predictors of cell phone dependence. As such, obtaining these benefits results in dependence on SNS. Therefore:

H1: Benefits positively impact dependence.

\section{Trust}

According to (Jackob, 2010), trust plays a vital role in almost all human interactions, including relationships with media such as SNS. Trust in SNS is the individual's expectation that the platform will act predictably, fulfilling its obligations while interacting with it (Kourouthanassis et al., 2015). Thus, people use Facebook to the extent that they perceive the SNS as safe and trustworthy (Lankton \& McKnight, 2011).

The perception of credibility, benevolence, and responsibility that users develop in the SNS enables trust (Kim \& Min, 2015; Wu et al., 2014). Also, SNSs allow having open and spontaneous interactions, which give way to the process of being connected (Bouman et al., 2007). This process helps build trust and strengthen relationships (Chiu et al., 2006; Ou et al., 2016; Sledgianowski \& Kulviwat, 2009).

In this context, the trust would imply a certain level of dependence on the SNS (Wells \& Kipnis, 2001). Thus, studies in media support the idea that trust is a relevant factor in the user's dependence. For example, (Jackob, 2010) suggests that people depend more on the medium when they present higher levels of trust towards it. (Len-Ríos et al., 2010) found that individuals who trusted alternative media more than conventional media were more dependent on the former than the latter in the context of health information. Thus:

H2. Trust has a positive impact on dependence.

\section{Usage}

Usage is the frequency of current activity a user has on the SNS. The experience gained through the frequent usage modifies individuals' cognitions, guiding their future behaviors (Neal et al., 2006; Turel \& Serenko, 2012). High engagement in the same behavior can aid learning processes that establish links between the behavior and the expected outcome. This pattern could be the basis upon which dependence is formed (Turel \& Serenko, 2012). Even though, if a person obtains substantial intrinsic rewards using a technology, 
further use would be more pleasurable or beneficial, facilitating the growth of dependence (Turel, 2015). Therefore:

H3. Usage positively influences dependence.

\section{Method}

The evaluation of the model was performed by collecting data using an online questionnaire and analyzing it through the partial least squares (PLS) technique.

The scales were adapted from previous studies. Table 2 summarizes the variables, sources, and examples of items. A 7-point Likert scale ( $1=$ totally disagree; $7=$ totally agree) was used for all seven variables.

Table 2: Measurement scales

\begin{tabular}{|c|c|c|}
\hline Construct & Source & Item example \\
\hline Relational & (Hu et al., 2015) & $\begin{array}{l}\text { Staying in touch with people is a great benefit of } \\
\text { using Facebook }\end{array}$ \\
\hline Informational & (Hu et al., 2015) & $\begin{array}{l}\text { Searching for information about people and social } \\
\text { activities is an excellent benefit of using Facebook. }\end{array}$ \\
\hline Enjoy & (Hu et al., 2015) & It is fun to use Facebook \\
\hline Curiosity & (Hu et al., 2015) & $\begin{array}{l}\text { Using Facebook satisfies my curiosity about people } \\
\text { and social activities }\end{array}$ \\
\hline Trust & (Chang \& Heo, 2014) & Facebook is a trustworthy social network \\
\hline Usage & (Park, 2014) & Currently, how often do you use Facebook? \\
\hline Dependence & (Ellison et al., 2007) & $\begin{array}{l}\text { I feel out of touch when I haven't logged onto } \\
\text { Facebook for a while }\end{array}$ \\
\hline
\end{tabular}

Data was collected from English-speaking Facebook users. The data collection platform was Amazon Mechanical Turk, which is effective for this purpose. Previous studies have reported that samples collected on this site produce similar results to those based on students and consumer panels (Steelman et al., 2014). Once incomplete cases were eliminated, 240 eligible questionnaires were obtained, which with the PLS technique, it is adequate to achieve high levels of statistical power according to the literature (Hair et al., 2011).

\section{Results}

The measurement model was evaluated through reliability, convergent validity, and discriminant validity according to the recommended values (Götz et al., 2010; Hair et al., 2011). Item reliability is shown since all item loadings were greater than the suggested cut-off 0.7 (Table 4 ). Internal consistency is observed as the $\mathrm{CR}$ and Cronbach alpha scores exceeded the recommended value of 0.7 (Table 4). Convergent validity is evidenced since the AVE values were greater than the suggested limit of 0.5 (Table 4). Finally, discriminant validity is established since the square root of the AVE is greater than the correlations between variables - Table 5 - (Chin, 1998). 
Issues in Information Systems

Volume 22, Issue 2, pp. 157-167, 2021

Table 4: Cronbach's $\alpha$, composite reliability (CR), average variance extracted (AVE), and range of factor loadings.

\begin{tabular}{ccccc}
\hline Variable & Cronbach's $\alpha$ & $C R$ & AVE & Range of factor loadings \\
\hline Relational & 0.958 & 0.969 & 0.887 & $0.936-0.951$ \\
Informational & 0.918 & 0.942 & 0.803 & $0.866-0.931$ \\
Enjoy & 0.960 & 0.971 & 0.894 & $0.889-0.971$ \\
Curiosity & 0.884 & 0.929 & 0.813 & $0.861-0.926$ \\
Trust & 0.957 & 0.969 & 0.887 & $0.897-0.957$ \\
Usage & 0.915 & 0.946 & 0.853 & $0.908-0.936$ \\
Dependence & 0.860 & 0.915 & 0.781 & $0.874-0.894$ \\
\hline
\end{tabular}

Table 5: Correlations, reliability, and the square root of the AVE

\begin{tabular}{|c|c|c|c|c|c|c|c|}
\hline \multirow{2}{*}{ Variable } & \multicolumn{7}{|c|}{ Correlations and the square root of AVE $(*)$} \\
\hline & Relational & Informational & Enjoy & Curiosity & Trust & Usage & Dependence \\
\hline Relational & 0.942 & & & & & & \\
\hline $\begin{array}{l}\text { Information } \\
\text { al }\end{array}$ & 0.672 & 0.896 & & & & & \\
\hline Enjoy & 0.657 & 0.582 & 0.945 & & & & \\
\hline Curiosity & 0.683 & 0.693 & 0.730 & 0.902 & & & \\
\hline Trust & 0.353 & 0.352 & 0.623 & 0.468 & 0.942 & & \\
\hline Usage & 0.478 & 0.481 & 0.714 & 0.545 & 0.533 & 0.924 & \\
\hline Dependence & 0.508 & 0.466 & 0.746 & 0.605 & 0.626 & 0.720 & 0.884 \\
\hline
\end{tabular}

Note $(*)$ : Diagonal numbers are the square root of the AVE for each construct.

Regarding the structural model, Figure 2 shows the standardized coefficients $(\beta)$, the significance level (all less than 0.01), and the explained variance of the latent variables. The variance explained for dependence is $64.3 \%$. Moreover, if the evaluation of the hypotheses results are statically significant, they are not rejected.

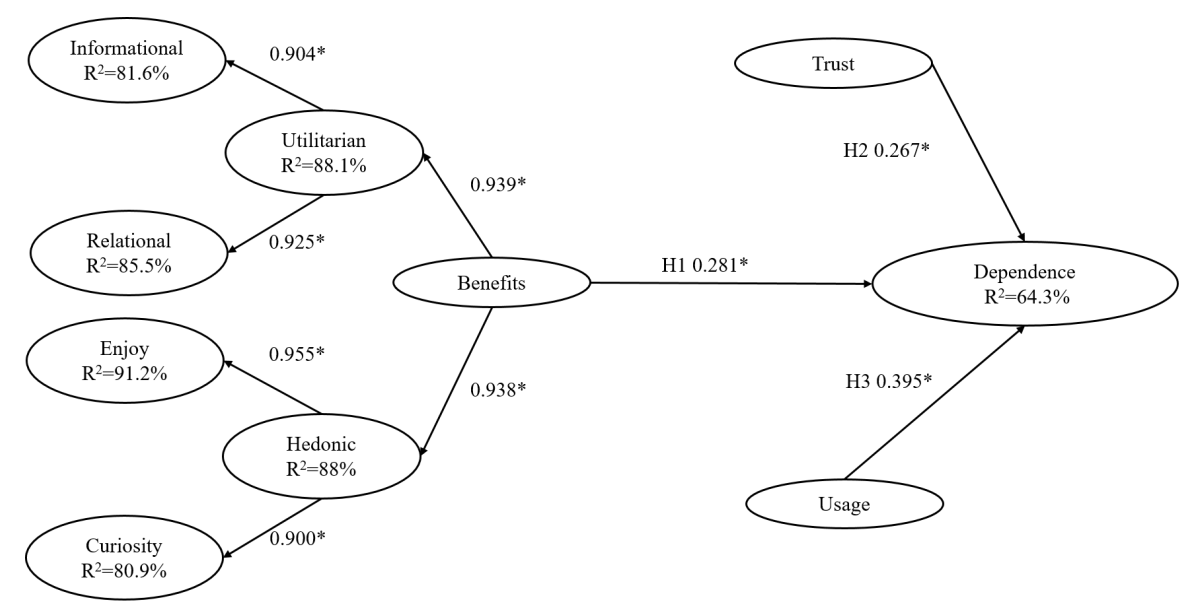

Figure 2: Results 


\section{Discussion}

The present study aimed to develop and empirically test a model that explains dependence on Facebook based on three factors: the benefits of SNS, trust, and the frequency of use. The main finding is that the model has empirical support for all these factors.

The main contributions to the literature are mentioned. First, unlike previous studies that treat dependence as an addiction (problematic use), this study defines dependence as the feeling of being hooked on the social network, which would be considered non-problematic use and a more widespread phenomenon in the population. Second, unlike previous literature based on MDT that positions dependence as a dependent variable to explain other phenomena, this study focuses on exploring the factors that contribute to dependence. Third, while benefits have been considered antecedents of dependence in the smartphone field, the multidimensional structure of benefits is a novel contribution of this study in the social networking arena. Finally, the model incorporates factors (trust and usage) that have been considered as precursors of dependence in other fields into the social networks arena.

Some practical implications are also mentioned. From the users' perspective, this study may warn them that their growing dependence stems mainly from the intensity and frequency of usage. Therefore, each individual must dose their use before becoming problematic. Likewise, users should be aware that, although this social network provides different benefits, the continuous attainment of these benefits may induce them to be more dependent. Individuals should seek alternative satisfiers to reduce extreme dependence.

Regarding limitations, the data collected pertains to adults, and there may be differences according to different age groups. Dependency patterns may vary between adolescents and adults. Younger people have a greater challenge in developing and maintaining meaningful interpersonal relationships (Reid \& Weigle, 2014). SNSs provide adolescents with opportunities to strengthen existing friendships and create new ones (Reid \& Weigle, 2014).

\section{References}

Agarwal, R., \& Karahanna, E. (2000). Time flies when you're having fun: Cognitive absorption and beliefs about information technology usage. MIS quarterly, 665-694.

Aslam, W., Arif, I., \& Farhat, K. (2018). Smartphone dependence among students: Gender-based analysis [Article]. International Journal of Electronic Marketing and Retailing, 9(3), 269-287. https://doi.org/10.1504/ijemr.2018.092696

Bianchi, C., Andrews, L., Wiese, M., \& Fazal-E-Hasan, S. (2017). Consumer intentions to engage in scommerce: a cross-national study [Article]. Journal of Marketing Management, 33(5-6), 464-494. https://doi.org/10.1080/0267257x.2017.1319406

Billieux, J., Philippot, P., Schmid, C., Maurage, P., De Mol, J., \& Van der Linden, M. (2015). Is dysfunctional use of the mobile phone a behavioural addiction? confronting symptom-based versus process-based approaches. Clinical psychology \& psychotherapy, 22(5), 460-468.

Bouman, W., de Bruin, B., Hoogenboom, T., Huizing, A., Jansen, R., \& Schoondorp, M. (2007). The realm of sociality: Notes on the design of social software. International Conference of Information Systems, Quebec, Canada. 


\section{Issues in Information Systems}

Volume 22, Issue 2, pp. 157-167, 2021

Burnell, K., \& Kuther, T. L. (2016). Predictors of Mobile Phone and Social Networking Site Dependency in Adulthood [Article]. Cyberpsychology, Behavior, and Social Networking, 19(10), 621-627. https://doi.org/10.1089/cyber.2016.0209

Chan, S. F., Barnes, B. R., \& Fukukawa, K. (2016). Consumer control, dependency and satisfaction with online service. Asia Pacific Journal of Marketing and Logistics.

Chang, C.-W., \& Heo, J. (2014). Visiting theories that predict college students' self-disclosure on Facebook. Computers in Human Behavior, 30, 79-86.

Chin, W. W. (1998). The partial least squares approach to structural equation modeling. In G. A. Marcoulides (Ed.), Modern methods for business research (Vol. 295, pp. 295-336). Psychology Press.

Chiu, C.-M., Hsu, M.-H., \& Wang, E. T. (2006). Understanding knowledge sharing in virtual communities: An integration of social capital and social cognitive theories. Decision Support Systems, 42(3), 1872-1888.

Chiu, C. M., \& Huang, H. Y. (2015). Examining the antecedents of user gratification and its effects on individuals' social network services usage: The moderating role of habit [Article]. European Journal of Information Systems, 24(4), 411-430. https://doi.org/10.1057/ejis.2014.9

Ellemers, N., Kortekaas, P., \& Ouwerkerk, J. W. (1999). Self-categorisation, commitment to the group and group self-esteem as related but distinct aspects of social identity. European journal of social psychology, 29(2-3), 371-389.

Ellison, N. B., Steinfield, C., \& Lampe, C. (2007). The benefits of Facebook "friends:" Social capital and college students' use of online social network sites. Journal of Computer-Mediated Communication, 12(4), 1143-1168.

Fan, L., Liu, X., Wang, B., \& Wang, L. (2017). Interactivity, engagement, and technology dependence: understanding users' technology utilisation behaviour [Article]. Behaviour and Information Technology, 36(2), 113-124. https://doi.org/10.1080/0144929x.2016.1199051

Ferris, A. L., \& Hollenbaugh, E. E. (2018). A Uses and Gratifications Approach to Exploring Antecedents to Facebook Dependency [Article]. Journal of Broadcasting and Electronic Media, 62(1), 51-70. https://doi.org/10.1080/08838151.2017.1375501

Gan, C., \& Wang, W. (2017). The influence of perceived value on purchase intention in social commerce context. Internet Research.

Gerhart, N. (2017). Technology addiction: How social network sites impact our lives [Article]. Informing Science, 20, 179-194. https://doi.org/10.28945/3851

Götz, O., Liehr-Gobbers, K., \& Krafft, M. (2010). Evaluation of structural equation models using the partial least squares (PLS) approach. In V. E. Vinzi, W. W. Chin, J. Henseler, \& H. Wang (Eds.), Handbook of partial least squares (pp. 691-711). Springer. 


\section{Issues in Information Systems}

Volume 22, Issue 2, pp. 157-167, 2021

Hair, J. F., Ringle, C. M., \& Sarstedt, M. (2011). PLS-SEM: Indeed a silver bullet. Journal of Marketing Theory and Practice, 19(2), 139-152.

Hooi Ting, D., Lim, S. F., Patanmacia, T. S., Low, C. G., \& Ker, G. C. (2011). Dependency on smartphone and the impact on purchase behaviour. Young Consumers, 12(3), 193-203.

Hu, T., Kettinger, W. J., \& Poston, R. S. (2015). The effect of online social value on satisfaction and continued use of social media. European Journal of Information Systems, 24(4), 391-410.

Huang, H. Y., Chen, P. L., \& Kuo, Y. C. (2017). Understanding the facilitators and inhibitors of individuals' social network site usage [Article]. Online Information Review, 41(1), 85-101. https://doi.org/10.1108/oir-10-2015-0319

Jackob, N. G. E. (2010). No alternatives? The relationship between perceived media dependency, use of alternative information sources, and general trust in mass media. International Journal of Communication, 4, 18.

Jung, J. Y. (2017). Media dependency theory. The international encyclopedia of media effects, 1-10.

Jung, J. Y., Lin, W. Y., \& Kim, Y. C. (2012). The dynamic relationship between East Asian adolescents' use of the internet and their use of other media [Article]. New Media and Society, 14(6), 969-986. https://doi.org/10.1177/1461444812437516

Keaveney, S. M., \& Parthasarathy, M. (2001). Customer switching behavior in online services: An exploratory study of the role of selected attitudinal, behavioral, and demographic factors. Journal of the academy of marketing science, 29(4), 374-390.

Kim, B., \& Min, J. (2015). The distinct roles of dedication-based and constraint-based mechanisms in social networking sites. Internet Research, 25(1), 30-51.

Kim, Y. C., \& Jung, J. Y. (2017). SNS dependency and interpersonal storytelling: An extension of media system dependency theory [Article]. New Media and Society, 19(9), 1458-1475. https://doi.org/10.1177/1461444816636611

Kourouthanassis, P., Lekakos, G., \& Gerakis, V. (2015). Should I stay or should I go? The moderating effect of self-image congruity and trust on social networking continued use. Behaviour \& Information Technology, 34(2), 190-203.

Lankton, N. K., \& McKnight, D. H. (2011). What does it mean to trust Facebook?: examining technology and interpersonal trust beliefs. ACM SIGMIS Database: The DATABASE for Advances in Information Systems, 42(2), 32-54.

Len-Ríos, M. E., Cohen, E., \& Caburnay, C. (2010). Readers use black newspapers for health/cancer information. Newspaper research journal, 31(1), 20-35.

Li, L., \& Lin, T. T. C. (2016). Exploring work-related smartphone dependency among young working adults in China: A qualitative approach [Article]. International Journal of Communication, 10, 2915$2933 . \quad$ https://www.scopus.com/inward/record.uri?eid=2-s2.085047918195\&partnerID=40\&md5=6690451229fcfa1538b09de665e09f22 


\section{Issues in Information Systems}

Volume 22, Issue 2, pp. 157-167, 2021

Lin, W. S., Chen, H. R., Lee, T. S. H., \& Feng, J. Y. (2019). Role of social anxiety on high engagement and addictive behavior in the context of social networking sites [Article]. Data Technologies and Applications, 53(2), 156-170. https://doi.org/10.1108/dta-09-2018-0076

Middleton, C. A., \& Cukier, W. (2006). Is mobile email functional or dysfunctional? Two perspectives on mobile email usage. European Journal of Information Systems, 15(3), 252-260.

Neal, D. T., Wood, W., \& Quinn, J. M. (2006). Habits-A repeat performance. Current directions in psychological science, 15(4), 198-202.

Ou, C. X., Davison, R. M., \& Huang, V. Q. (2016). The Social Networking Application Success Model: An Empirical Study of Facebook and Twitter. International Journal of Knowledge Content Development \& Technology, 6(1), 5-39.

Park, J.-H. (2014). The effects of personalization on user continuance in social networking sites. Information processing \& management, 50(3), 462-475.

Park, N., Kim, Y. C., Shon, H. Y., \& Shim, H. (2013). Factors influencing smartphone use and dependency in South Korea [Article]. Computers in Human Behavior, 29(4), 1763-1770. https://doi.org/10.1016/j.chb.2013.02.008

Reid, D., \& Weigle, P. (2014). Social media use among adolescents: Benefits and risks. Adolescent Psychiatry, 4(2), 73-80.

Rosaline, S., \& Johnson, S. (2020). Continued usage and dependency of smartphones [Article]. International Journal of Cyber Behavior, Psychology and Learning, 10(1), 41-53. https://doi.org/10.4018/ijcbpl.2020010104

Sanz-Blas, S., Bigné, E., \& Buzova, D. (2017). M-WOM in a brand's facebook fan page [Article]. Online Information Review, 41(7), 936-953. https://doi.org/10.1108/oir-08-2016-0237

Sledgianowski, D., \& Kulviwat, S. (2009). Using social network sites: The effects of playfulness, critical mass and trust in a hedonic context. Journal of Computer Information Systems, 49(4), 74-83.

Statista. (2019a). Number of monthly active Facebook users worldwide as of 2nd quarter 2019 (in millions). Retrieved September 01 from https://www.statista.com/statistics/264810/number-of-monthlyactive-facebook-users-worldwide/

Statista. (2019b). U.S. internet users addicted to social media 2019, by age group. Retrieved May 01 from https://www.statista.com/statistics/1081292/social-media-addiction-by-age-usa/

Statista. (2020). Frequency of Facebook use in the United States as of 3rd quarter 2020. H. Tankovska.

Steelman, Z. R., Hammer, B. I., \& Limayem, M. (2014). Data collection in the digital age: Innovative alternatives to student samples. MIS quarterly, 38(2), 355-378.

Suki, N. M. (2013). Students' dependence on smart phones: The influence of social needs, social influences and convenience [Article]. Campus-Wide Information Systems, 30(2), 124-134. https://doi.org/10.1108/10650741311306309 


\section{Issues in Information Systems}

Volume 22, Issue 2, pp. 157-167, 2021

Tian, L., Shi, J., \& Yang, Z. (2009). Why does half the world's population have a mobile phone? An examination of consumers' attitudes toward mobile phones. CyberPsychology \& Behavior, 12(5), 513-516.

Turel, O. (2015). An empirical examination of the "vicious cycle" of Facebook addiction. Journal of Computer Information Systems, 55(3), 83-91.

Turel, O., \& Serenko, A. (2012). The benefits and dangers of enjoyment with social networking websites [Article]. European Journal of Information Systems, 21(5), 512-528. https://doi.org/10.1057/ejis.2012.1

Wells, C. V., \& Kipnis, D. (2001). Trust, dependency, and control in the contemporary organization. Journal of Business and Psychology, 15(4), 593-603.

Wu, C.-C., Huang, Y., \& Hsu, C.-L. (2014). Benevolence trust: a key determinant of user continuance use of online social networks. Information Systems and e-Business Management, 12(2), 189-211. 